\title{
Traditional Caymanian fishery may impede local marine turtle population recovery
}

\author{
Catherine D. Bell ${ }^{1,2, *}$, Janice M. Blumenthal ${ }^{1,3}$, Timothy J. Austin ${ }^{3}$, Joni L. Solomon ${ }^{3}$, \\ Gina Ebanks-Petrie ${ }^{3}$, Annette C. Broderick ${ }^{1}$, Brendan J. Godley ${ }^{1}$ \\ ${ }^{1}$ Marine Turtle Research Group, Centre for Ecology and Conservation, University of Exeter, Cornwall Campus, \\ Penryn TR10 9E2, UK \\ ${ }^{2}$ Cayman Turtle Farm (1983) Ltd., PO Box 812 WB, Grand Cayman, Cayman Islands, British West Indies \\ ${ }^{3}$ Department of Environment, PO Box 486, George Town, Grand Cayman, Cayman Islands, British West Indies
}

\begin{abstract}
Many marine turtle populations are smaller than they once were, having been exploited at varying levels since prehistory. However, in areas where exploitation of adults has been substantially reduced or halted, increases in local nesting populations of several species have been shown. There is a paucity of published information on catch rates, methodologies, target species and size classes in small scale marine turtle fisheries. In the Cayman Islands a legal, highly regulated turtle fishery exists; laws regarding turtle protection regulate seasonality, capture location and method, size class, and levels of take via a licensing system. Licenses have only been issued to 'traditional' fishermen and will not be issued to other individuals in the future. Analysis of fishery data from legally captured animals $(n=27)$ shows that all turtles reported as captured were either adults or very large juveniles, and many were captured during periods when adults were likely to have been in the waters of the Cayman Islands to breed. We conclude that, given the critically small size of the local nesting populations, it is possible that this directed take, although at very low levels in regional terms, may impede the local population recovery sought through other conservation and management steps being taken in the Cayman Islands.
\end{abstract}

KEY WORDS: Cayman · Turtle $\cdot$ Fishery $\cdot$ Traditional $\cdot$ Conservation $\cdot$ Resource management Resale or republication not permitted without written consent of the publisher

\section{INTRODUCTION}

Marine turtles are considered of global conservation concern (IUCN 2006) and have been exploited at varying levels since prehistory. Take intensified from the seventeenth century (Jackson 1997) to provide products for a developing international trade, as well as local subsistence. Trade restrictions agreed by countries signatory to the Convention on International Trade in Endangered Species (CITES) have in the last few decades eliminated many markets for turtle products worldwide (e.g. the US and UK), and some Caribbean states have gone a step further by banning turtle fisheries, for example Bermuda (King 1982). Some fisheries persist, for example in the Bahamas
(Bjorndal et al. 2003), Cuba (Carrillo et al. 1999), Haiti (Fleming 2001), Montserrat (Martin et al. 2004) and Turks and Caicos (Godley et al. 2004). In areas where the exploitation of breeding adults has been substantially reduced or abolished and other management practices have been implemented, data show increases in local nesting populations of several species within comparatively short time periods. This includes green turtles Chelonia mydas (Hawaii, Balazs \& Chaloupka 2004; Costa Rica, Troeng \& Rankin 2005; Ascension Island, Broderick et al. 2006), leatherback turtles Dermochelys coriacea (US Virgin Islands, Dutton et al. 2005; British Virgin Islands, Hasting 2003) and hawksbill turtles Eretmochelys imbricata (Barbados, Krueger et al. 2003). 
Although in relatively recent times some Caribbean turtle fisheries and their potential impacts on populations have been described (e.g. Nicaragua, Lagueux 1998; Western Caribbean, Parsons 1962), there is a paucity of up-to-date published information on catch rates, methodologies, target species and size classes within remaining fisheries. Analysis of these types of data allows management bodies to assess the likely impacts of their fisheries on remaining stocks and to modify laws and regulations to ensure effective management of remaining populations.

Historically, nesting sea turtles were highly abundant in the Cayman Islands (Williams 1995) and it has been suggested that these islands supported the largest green turtle rookery in the Caribbean (Groombridge 1982, King 1982). Records indicate that by 1655 , in addition to the Spanish, English and French who had been using the resource when passing the Cayman Islands, the British Colony in Jamaica had begun systematic plundering of the population. Turtles were turned on the beach in Cayman and with 40 sloops engaged full time, each carrying as many as 30 to 50 nesting females which could be captured in a night, the fleet was bringing in upwards of 13000 turtles a year. By the late 1700s only a few turtles nested in Cayman each year, and by 1840, fishermen would travel as far as the Miskito Cays, Nicaragua, to catch turtles for sale and consumption (King 1982). By 1900 it was believed that the local reproductive population of marine turtles had been extirpated (Stoddart 1980, Groombridge 1982, King 1982). It was through this activity, however, that the economy and seafaring traditions of the Cayman Islands were established.

More recently, Wood \& Wood (1994) reported 78 marine turtle nests by 4 species of marine turtle (green, loggerhead Caretta caretta, hawksbill and leatherback) between 1971 and 1991. Systematic surveys of nesting in the Cayman Islands begun in 1998 (Aiken et al. 2001), identified small numbers of green and loggerhead turtles nesting annually (17 to 26 females of each species (Bell et al. in press) with occasional nesting by the hawksbill turtle $\left(<1\right.$ female $\left.\mathrm{yr}^{-1}\right)$. These numbers indicate populations that, at least for green and loggerhead turtles, are stable, although massively smaller than in historical records.

Concerns regarding diminished numbers of marine turtles in the Cayman Islands drove the need to regulate wild marine turtle capture in 1978. As part of a larger suite of marine conservation legislation passed in the same year (the Marine Conservation Law and Regulations), the Turtle Protection Regulations were established prohibiting possession of eggs and interference with nesting females from May through September only (Cayman Islands Government 1978). In 1985 these regulations were amended and a new closed season was established from 1 May to 31 October, with turtle fishing during an open season governed by licenses issued only to Caymanians who had been taking turtles by traditional methods, for consumption within the Cayman Islands (Frazer 1985). The new licenses stipulated a minimum size limit to discourage capture of juveniles $(36.4 \mathrm{~kg} / 80 \mathrm{lb}$ hawksbill, $54.5 \mathrm{~kg} / 120 \mathrm{lb}$ green and loggerhead turtles), limited annual take to 6 turtles total per licensee, capture methods to 'traditional' means only and restricted capture location to outside the reef and Marine Park Areas which, in the case of there being no reef, end at the $24 \mathrm{~m}$ (80 ft) depth contour (Cayman Islands Government 1996). Traditional fishing methods include the use of 'trap or set nets' only. A trap net is a coneshaped net attached to a weighted steel hoop which provides the opening for entrapment. It is lowered onto turtles either resting on the bottom or swimming mid water. A set net is a traditional rectangular-shaped net with a 6 to $10 \mathrm{~cm}$ ( 3 to 4 inch) mesh, weighted with lead at the bottom and a floated line at the top. In some cases it is moored at both ends, and in others only one end is moored and the other is allowed to swing free. Both methods aim to ensure the turtle is still alive when it is brought ashore.

License holders are required to apply 1 of 6 tags (issued per licensee and distributed at the start of each season) to each captured turtle and report all captures to a Fisheries Officer at the Department of Environment before slaughter. This aims to allow for inspection, verification of weight and collection of other biological data. However, this aspect of the license requirements was not actively enforced until resources became available in 1999. In 1996 the Marine Conservation Board, an elected statutory board of 12 members established in 1978 under the Marine Conservation Law to administer the legislation, placed a permanent moratorium on the issue of licenses. No new licenses have been issued since that time, and although existing licenses can be renewed indefinitely by the licensee in possession, no new applications will be considered (P. Bush, Marine Conservation Board, pers. comm.).

Although highly restricted, the fishery has been allowed to continue in order to preserve the traditional and cultural practices of Caymanian fishermen. The activity is no longer essential to income or sustenance; Cayman's economy has become reliant upon the tourism and financial sectors, and standards of living are considered high (per capita GDP US \$32 300, CIA 2006, available at https://www.cia.gov/cia/publications/factbook/geos/cj.html). A small number of traditional fishermen are still permitted to renew existing licenses each year. At the time of writing, 22 individuals are eligible to fish for turtle and 14 licenses are cur- 
rent. Eligible fishermen range from 44 to 88 years of age. It is anticipated that the fishery will diminish and eventually cease; however, in the interim, a phase which may last for several decades more, it is important to profile the fishery and assess its likely impact on surviving populations of marine turtles. This study set out to thoroughly examine legal turtle capture data collected by the Cayman Islands Government Department of Environment.

\section{MATERIALS AND METHODS}

The Cayman Islands are located in the Caribbean Sea (Grand Cayman $19.3^{\circ} \mathrm{N}, 81.4^{\circ} \mathrm{W}$; Little Cayman $19.7^{\circ} \mathrm{N}, 81.1^{\circ} \mathrm{W}$; Cayman Brac $19.7^{\circ} \mathrm{N}, 79.9^{\circ} \mathrm{W}$ ) (Fig 1).

All turtle fisheries data collected from 1999 to 2004 were reviewed to profile the catch and assess its possible impact on nesting populations. Where possible, data collected included date, location and method of capture, species, sex, carapace length, and estimated body weight. Collection of weight data was limited by the maximum range of the scale; animals exceeding $91 \mathrm{~kg}(200 \mathrm{lb})$ could not be accurately weighed and are presented in 1 category of $>91 \mathrm{~kg}$.

In the absence of unequivocal maturity assessment methods, likely adulthood was ascribed based on bodyweight; >75 kg (165 lb) for loggerhead turtles (Márquez 1990), >100 kg (221 lb) for green turtles (USFWS 1980b), and >44 kg (97 lb) for hawksbill turtles (Martin et al. 2005) where these data were available. Adult males could be assessed by their external morphological characteristics, i.e. the pres-

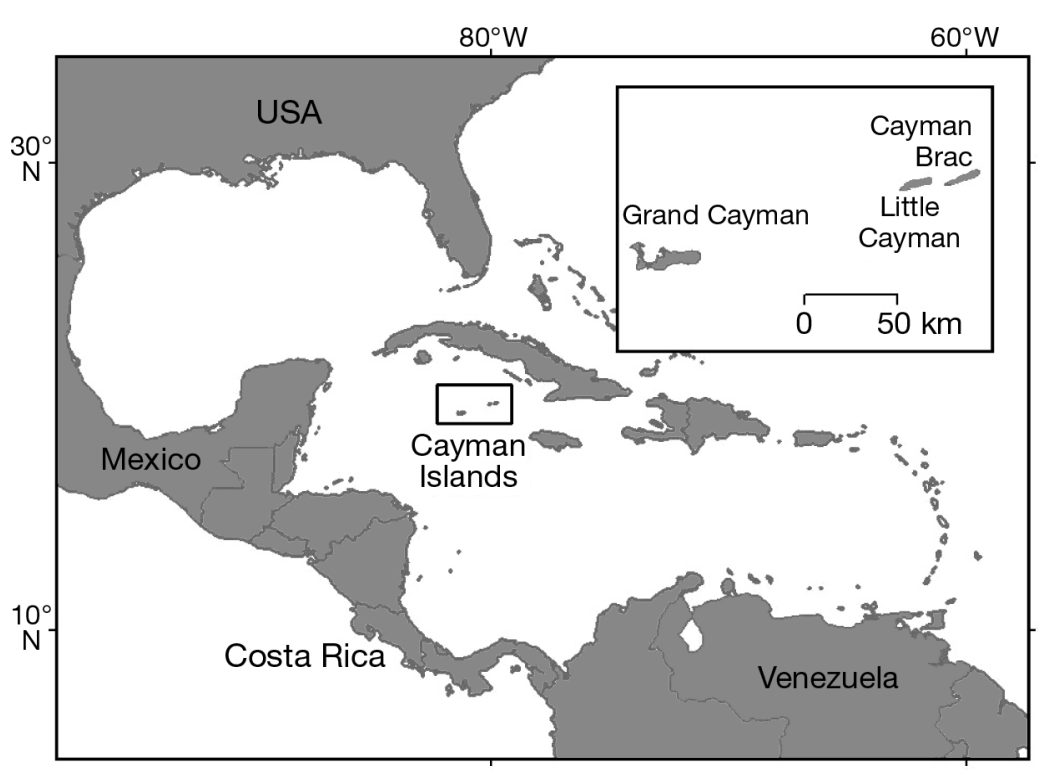

Fig. 1. Location of the Cayman Islands within the Caribbean Sea ence of a tail well extended beyond the supracaudal scutes. The sex of others was classified as unknown.

\section{RESULTS}

Data regarding the seasonality of 27 legally captured turtles (green turtles, $\mathrm{n}=14$; loggerhead turtles, $\mathrm{n}=3$; hawksbill turtles, $\mathrm{n}=10$ ) recorded between April 1999 and April 2004, are presented in Fig. 2a. Although captures are recorded in every month of the 6 mo open season (1 November to 30 April), $60 \%$ (16) of all captures were recorded in April.

The weights of 12 captured turtles in the category $<91 \mathrm{~kg}(200 \mathrm{lb})$ are given in Fig. 2b. A further 7 green and 2 loggerhead turtles were captured weighing $>91 \mathrm{~kg}$ (200 lb). The vast majority of turtles reported captured were either very large juveniles or adults. Recorded weights of animals within the scale capacity are as follows: (mean $\pm \mathrm{SD}$, range): green turtles $67 \mathrm{~kg}$ $\pm 11.9,55$ to $82 \mathrm{~kg}, \mathrm{n}=4$; loggerhead turtles $70 \mathrm{~kg}$ $\mathrm{n}=1$; hawksbill turtles $43 \mathrm{~kg} \pm 6.2,37$ to $54 \mathrm{~kg}, \mathrm{n}=7$. A further 7 green and 2 loggerhead turtle captures were not included as their weight exceeded $91 \mathrm{~kg}$.

The ratio of male individuals to those of unknown sex was 8:4 for green turtles, 1:2 for loggerhead turtles and 1:9 for hawksbill turtles captured. Mean (range) annual level of recorded take of large, possible adults as defined by weight criteria between 1999 and 2004 is 1 (0 to 2) green, 0.4 (0 to 1) loggerhead, and 1 (0 to 4) hawksbill turtles. To contextualize this take, total adult female (nesting) numbers for the same period are estimated as 17 to 26 for both green and loggerhead turtles (Bell et al. in press) based on a mean of 3 nests laid per female in each breeding migration (Seminoff 2004). For hawksbill nesting, the last clutches recorded were in Little Cayman in 1998 and Grand Cayman in 1999 (Aiken et al. 2001).

Capture methods were recorded in $68 \%$ of all cases and capture location in all but one case (Fig. 3). Where capture method was recorded, all hawksbill turtles captured in Cayman Brac or Little Cayman were captured using a set net (19\% of total number of turtle captured) and all turtles captured in Grand Cayman were captured using a trap net. Where depth of capture was recorded all entries were reported as taking place outside the reef contour or beyond the $24 \mathrm{~m}(80 \mathrm{ft})$ contour, as appropriate. Of all captures recorded in Grand Cayman the vast majority $(87 \%)$ were captured on the eastern section of the north coast (Fig. 3). 

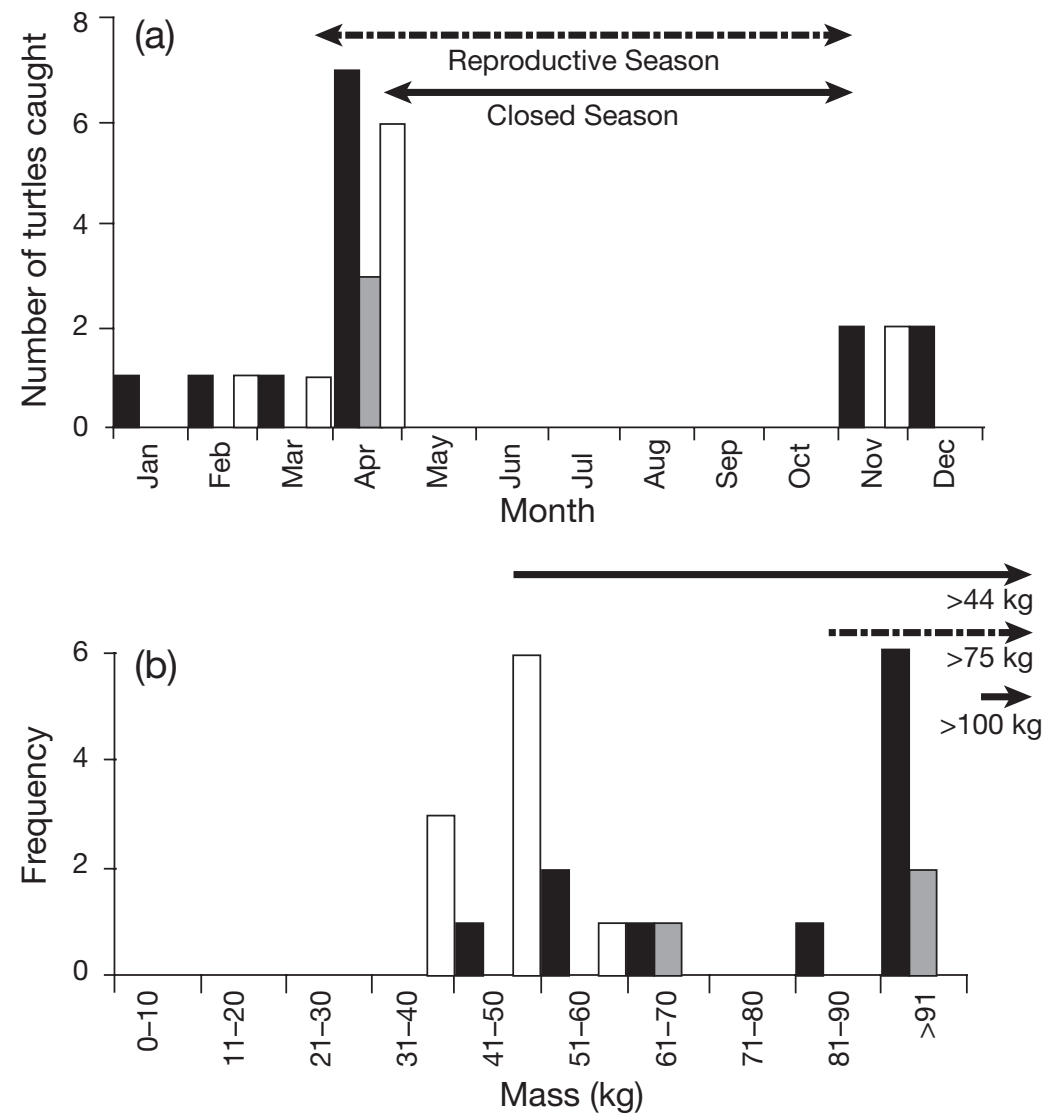

Fig. 2. Legal capture data. (a) Temporal distribution of legal captures recorded in the Cayman Islands between April 1999 and April 2004, shown in relation to the timing of the fishery open season and reproductive phenology (including mating and nesting). (b) Weight (kg) of legally captured turtles by species between April 1999 and April 2004. White bars = Eretmochelys imbricata, black bars $=$ Chelonia mydas, grey bars $=$ Caretta caretta . Long solid line indicates E. imbricata size at maturity, dashed line C. caretta size at maturity and short solid line C. mydas size at maturity

\section{DISCUSSION}

A fishery that forces a focus on take of large individuals and overlaps with the breeding season of such small populations can potentially negatively impact or slow any recovery resulting from other conservation and management steps being taken in the Cayman Islands and further afield. Marine turtles are slow to mature; individuals are therefore not rapidly replaced (Heppell 1996). Though it appears from our data that fishermen do not fulfill their quota, under current regulations they are legally entitled to remove as many as 132 turtles per annum, which could conceivably encompass the entire annual breeding cohort of all species. It must also be recognized that catch may only be reported for legal size animals during the 'open' months, in the legal locations and using the permitted methods.

Furthermore, ongoing reports from enforcement officers and local individuals suggest unknown levels of illegal take (undersized, unlicensed, out of season and out of range) occurring around all 3 islands; though penalties have existed since 1985, the first successful prosecution for this crime was in 2003 and only 5 individuals have been prosecuted in total since the introduction of penalties (Mark Orr, Marine Enforcement Supervisor, Department of Environment, pers. comm.). There is a maximum penalty for this crime of up to CI \$ 500 000/US \$ 625000 and/or up to one year in jail and loss of all equipment used to capture turtles, although to date, fines of not more than CI \$1500/US $\$ 1800$ have been applied. Annual estimates of number of individuals lost have, in the past, placed the scale of poaching to be in the region of $10+$ individuals per year (Aiken et al. 2001) although with the increase of enforcement and prosecution, this number is currently believed to have decreased to <10 per year (Mark Orr, pers. comm.).

Adult marine turtles are generally migratory, returning to distant foraging grounds after breeding (Musick \& Limpus 1997). Recent satellite tracking data confirm that adult female green and loggerhead turtles leave Cayman waters after the breeding season (Blumenthal et al. in press), highlighting the distant foraging grounds of these animals. Potentially, fishing activities in these foraging grounds can also significantly impact numbers.

Most turtles captured in the Cayman Islands were recorded during the open season in April when the presence of adults in Caymanian waters is most likely attributed to reproductive effort. Nesting in Cayman occurs between April-October (Aiken et al. 2001a, Bell et al. in press) and mating is known to occur approximately 1 mo prior to nesting (Godley et al. 2002, Hirth 1997, Dodd 1998). The relatively high frequency of turtles captured during these months may be either the result of increased numbers of turtles in Cayman waters, increased capture effort among fishermen targeting large individuals when they are known to be present in Caymanian waters for breeding, or a combination of these factors.

The higher incidence of male green turtles captured may be a result of previous take being focussed on nesting beaches, differing sex-specific survival rates, sex-specific migratory patterns or evidence of a high proportion of males in the population as a result of nat- 


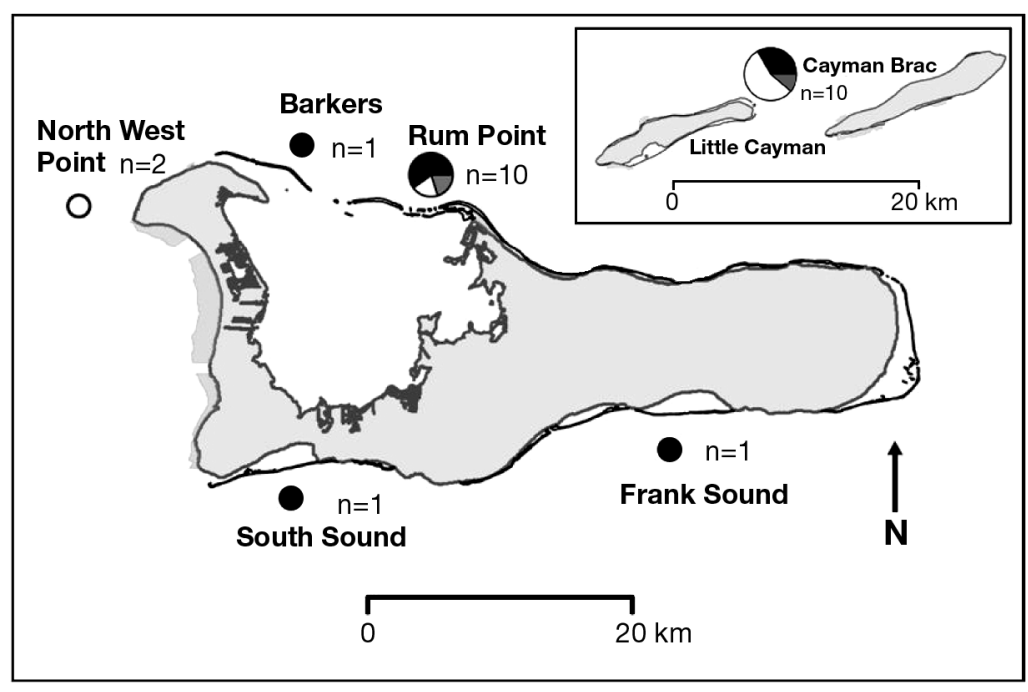

Fig. 3. Grand Cayman and (inset) Cayman Brac and Little Cayman, also known as the Sister Islands. Divisions within the circles represent the proportion of animals of each species captured at each location. White area = Eretmochelys imbricata, black $=$ Chelonia mydas, grey $=$ Caretta caretta . Shaded offshore areas are Marine Park Zones in which taking of any marine life, alive or dead, is prohibited. Offshore lines indicate the reef contour

extirpated. This is probably the result of direct fisheries exploitation over extended timescales, which in many cases will have been exacerbated by take of nesting females and eggs on the beach. It seems clear that, in the interests of sustainability, the Cayman Islands must reassess their marine turtle fishery legislation. The biological advantages of a cessation or, at the very least, further restrictions on such a fishery are clear and the economic impacts negligible, indeed potentially negative, given the tourism-based economy of the Cayman Islands. Although the sociocultural impacts of license removal would be restricted to the limited number of individuals licensed to fish, consideration must be given, as turtle fishing or 'turtling' is a long-standing Caymanian tradition. While turtle meat is still considered an acceptable and enjoyable food in the Cayman Islands, it is no longer an essential component of

urally skewed primary sex ratios. There is also potential for bias resultant from the methods used to sex mature turtles in this study. Green turtles have been the subject of ex situ conservation efforts at the Cayman Turtle Farm in the form of a headstarting and release programme, in operation since 1980 (Bell et al. 2005). Artificial hatchery conditions at the Cayman Turtle Farm during the early years after its inception may have produced male skewed sex ratios, as has been shown for styrofoam box use during artificial incubation for Kemps' ridley (Wibbels et al. 1989) and leatherback turtles (Dutton et al. 1985). This would have been the case for turtles subject to headstarting and release. Although none of the turtles captured in the fishery bore a Cayman Turtle Farm tag, headstarted turtles have been recaptured at intervals of up to $19 \mathrm{yr}$ and many turtles were released untagged (Bell et al. 2005). Finally, the sex bias may also reflect behavioral characteristics that encourage capture of male turtles. Male turtles exhibit 'scramble mate finding' tactics, and may consequently be more active in their search for partners/breeding females (Jessop et al. 1999). The adult hawksbill turtles captured in the fishery despite very little recent nesting may represent the few remaining adults of this population. The Cayman Islands may, however, also be a foraging ground or part of a migratory route for adults of this species.

A recent review of the status of marine turtle nesting populations in the UK Overseas Territories in the Caribbean (Godley et al. 2004) highlighted that in all territories, nesting populations are greatly reduced or the diet. Turtle dishes are often central to special social occasions but meat from the Cayman Turtle Farm is available to satisfy this demand. Sale of wild turtle meat is no longer relied upon for income; the Cayman Islands enjoy a highly developed and stable economy. In addition to use as a food source, marine turtles are the national symbol of the Cayman Islands. While it could be argued that capture of turtles is considered a necessity in order to allow tradition to survive, the potential loss of an integral component of Cayman's national heritage must be weighed up against the traditions of a handful of remaining fishermen.

Continuation of marine turtle fishing must also be reviewed in light of the conditions of the Convention on Migratory Species, to which the Cayman Islands are a signatory party. Under the convention, take of turtles may be permitted for 'traditional subsistence users' as 'subsistence use' (CMS 2003, available at http://www.cms.int/documents/convtxt/cms_convtxt.htm; Richardson et al. 2006). It is not clear whether turtle fishermen in the Cayman Islands meet these criteria; although they were traditionally subsistence users, today alternative sources of protein are readily available and standards of living are considered high. In May 2004 the Cayman Islands Marine Conservation Board voted to ban the take of all wild turtles at all lifestages at all times, and recommended that at the very least, steps should be taken to minimize the impact on breeding adult turtles (P. Bush, Marine Conservation Board, pers. comm.). At the time of writing it is not yet clear, however, if these recommendations will be 
enacted either in part (i.e. implementation of a maximum size limit to protect reproductive adults) or in full (i.e. a complete ban). In other Caribbean nations, legal and associated illegal take have been identified as one of the most serious threats to recovery (Opay 1998, Troeng 1998, Troeng \& Gonzales-Rankin 2000). Where enough time has passed, it is suspected that this has aided the increase of turtle populations (Troeng et al. 2002, Troeng \& Rankin 2005). The biological advantage of protecting adult populations, particularly during the reproductive season, is known, and must be implemented in Cayman as a minimum. If the fishery were to stay open, we recommend that the closed season be extended to include March, April and November and that restrictions on size limit be amended to focus the fishery on smaller individuals, rather than larger animals, both adult and sub-adult, of higher current or future reproductive value.

Acknowledgements. We thank both the Enforcement Unit and Fisheries Officers of the Cayman Islands Department of Environment and those local fishermen whose catch was reported for facilitating the collection of these data. This work was supported by a National Fish and Wildlife Foundation (NFWF) Grant (Cayman Islands), and B.J.G. and A.C.B. acknowledge the additional support of the Darwin Initiative, European Social Fund, the Foreign and Commonwealth Office Environment Fund for the Overseas Territories Environment Programme. J.M.B. is supported by a University of Exeter postgraduate scholarship. The manuscript benefited from the constructive review of 3 anonymous referees.

\section{LITERATURE CITED}

Aiken JJ, Godley BJ, Broderick AC, Austin TJ, Ebanks-Petrie G, Hays GC (2001) Two hundred years after a commercial marine turtle fishery: the current status of marine turtles nesting in the Cayman Islands. Oryx 35:145-151

Balazs GH, Chaloupka M (2004) Thirty-year recovery trend in the once depleted Hawaiian green turtle stock. Biol Conserv 117:491-498

Bell CD, Parsons J, Austin TJ, Broderick AC, Ebanks-Petrie G, Godley BJ (2005) Some of them came home: The Cayman Turtle Farm headstarting project. Oryx 39: $137-148$

Bell CD, Solomon J, Blumenthal J, Austin TJ, Ebanks-Petrie G, Broderick AC, Godley BJ (in press) Monitoring and conservation of critically reduced marine turtle nesting populations: Lessons from the Cayman Islands. Anim Conserv

Bjorndal KA, Bolten AB, Chaloupka MY (2003) Survival probability estimates for immature green turtles Chelonia mydas in the Bahamas. Mar Ecol Prog Ser 252:273-281

Blumenthal J, Solomon J, Bell C, Austin TJ, Ebanks-Petrie G, Coyne M, Broderick A, Godley BG (2006) Satellite tracking highlights the need for international cooperation in marine turtle management. Endang Species Res 1:1-11

Broderick AC, Fraunstein R, Glen F, Hays GC, Jackson AL, Pelembe T, Ruxton GD, Godley BJ (2006) Are green turtles globally endangered? Glob Ecol Biol 15:21-26
Carrillo E, Webb GJW, Manolis C (1999) Hawksbill turtles (Eretmochelys imbricata) in Cuba: an assessment of the historical harvest and its impacts. Chelonian Conserv Biol $3(2): 264-280$

Cayman Islands Government (1978) Marine Conservation Law Supplement 7. Published with Gazette no. 20, Government of the Cayman Islands, Cayman Islands

Cayman Islands Government (1996) Marine Conservation (Turtle Protection) Regulations (1996 Revisions). Supplement No. 4. Published with Gazette no. 15 of 22nd July, 1996, Government of the Cayman Islands, Cayman Islands

Dodd KC Jr (1998) Synopsis of the biological data on the loggerhead sea turtle Caretta caretta (Linnaeus 1758). US Fish and Wildlife Service, NMFS-149, Biological Report $88: 14$

Dutton PH, Whitmore CD, Mrosovsky N (1985) Masculinisation of leatherback (Dermochelys coriacea) hatchlings from eggs incubated in styrofoam boxes. Biol Conserv 31: 249-264

Dutton PH, Chaloupka M, Boulon RH (2005) Increase of a Caribbean leatherback turtle Dermochelys coriacea nesting population linked to long term nest protection. Biol Conserv 126:186-194

Flemming EH (2001) Swimming against the tide: Recent surveys of exploitation, trade and management of marine turtles in the Northern Caribbean. TRAFFIC North America, Washington, DC

Frazer NB (1985) New Cayman Turtle Law. Mar Turtle Newsl $35: 9$

Godley BJ, Broderick AC, Frauenstein R, Glen F, Hays GC (2002) Reproductive seasonality and sexual dimorphism in green turtles. Mar Ecol Prog Ser 226:125-133

Godley BJ, Broderick AC, Campbell LM, Ranger S, Richardson $P$ (2004) An assessment of the status and exploitation of marine turtles in the United Kingdom Overseas Territories in the wider Caribbean. Final Project Report for the Department of Environment, Food and Rural Affairs and the Foreign and Commonwealth Office. Available at: www.seaturtle.org/mtrg/projects/tcot/finalreport/

Groombridge B (1982) The IUCN Amphibia-Reptilia Red Data book. IUCN, Gland

Hasting M (2003) A conservation success: leatherback turtles in the British Virgin Islands. Mar Turtle Newsl 99:5-7

Heppel SS, Limpus CJ, Crouse DT, Frazer NB, Crowder LB (1996) Population model analysis for the loggerhead sea turtle, Caretta caretta, in Queensland. Wildl Res 23: 143-161

Hilton-Taylor C (2000) IUCN Red List of threatened species. IUCN, Gland

Hirth HF (1997) Synopsis of the biological data on the green turtle Chelonia mydas (Linnaeus 1758). Biological report, US Fish and Wildlife Service 97:1

IUCN (2006) The IUCN Red List of threatened species. Available at: www.iucnredlist.org

Jackson JBC (1997) Reefs since Columbus. Coral Reefs 16 (Suppl): S23-S32

Jessop TS, FitzSimmons NN, Limpus CJ, Whittier JM (1999) Interactions between behavior and plasma steroids within the scramble mating system of the promiscuous green turtle, Chelonia mydas. Horm Behav 36:86-97

King FW (1982) Historical review of the decline of the green turtle and the hawksbill. In: Bjorndal KA (ed) Biology and conservation of sea turtles. Smithsonian Institute Press, Washington, DC, p 183-188

Krueger B, Horrocks J, Beggs J (2003) Increase in nesting activity by hawksbill turtles (Eretmochelys imbricata) in Barbados. In: Seminoff JA (ed) Proc 22nd Annu Symp 
Sea Turtle Biology and Conservation. NOAA Tech Memo NMFS-SEFSC-503

Lagueux CJ (1998) Marine turtle fishery of Caribbean Nicaragua: human use patterns and harvest trends. $\mathrm{PhD}$ dissertation. University of Florida, Gainesville, FL

Martin CS, Jeffers J, Godley BJ (2005) The status of marine turtles in Montserrat (Eastern Caribbean). Anim Biodiv Cons 28:159-168

Márquez R (1990) FAO Species Catalogue: sea turtles of the world. FAO Fisheries Synopsis no. 125, Vol 11

Musick JA, Limpus CJ (1997) Habitat utilisation and migration in juvenile sea turtles. In: Lutz PL, Musick JA (eds) The biology of sea turtles. CRC Press, Boca Raton, FL, p 137-163

Opay P (1998) Legal action taken to stop the hunting of green turtles in Costa Rica. Mar Turtle Newsl 79:12-16

Parsons JJ (1962) The green turtle and man. University of Florida Press, Gainesville, FL

Richardson PB, Broderick AC, Campbell LM, Godley BJ, Ranger S (2006) Marine turtle fisheries in the UK Overseas Territories of the Caribbean: Domestic legislation and the requirements of multilateral agreements. J Int Wildl Law Pol 9:223-246

Seminoff JA (2004) IUCN Red List Status Assessment green turtle (Chelonia mydas). Marine Turtle Specialist Group, IUCN, Gland

Stoddart DR (1980) Little Cayman: ecology and significance. Atoll Res Bull 241:171-180

Troeng S (1998) Poaching threatens the green turtle rookery at Tortuguero, Costa Rica. Mar Turtle Newsl 79:11-12

Editorial responsibility: Luca Luiselli,

Rome, Italy
Troeng S, Gonzales-Rankin SA (2000) Illegal harvesting of nesting green turtles Chelonia mydas in Tortuguero National Park, Costa Rica. In: Abreu-Grobois FA, BrisenoDuenas R, Marquez R, Sarti L (eds) Proc 18th Int Sea Turtle Symp. US Dept. of Commerce. NOAA Tech Memo NMFS-SEFSC-436, p 30-31

Troeng S, Chamorro E, Silman R, (2002) Ban and benefits: Tortuguero at 2000. In: Proc 20th Annu Symp Sea Turtle Biology and Conservation. US Dept. Commerce. NOAA Tech Memo NMFS-SEFSC-477, p 43

Troeng S, Rankin E (2005) Long term conservation efforts contribute to positive green turtle Chelonia mydas nesting trend at Tortuguero, Costa Rica. Biol Conserv 121:111-116

US Fish and Wildlife Service (USFWS) (1980) Selected vertebrate endangered species of the seacoast of the United States. US Fish and Wildlife Service. FWS/OBS-80/01

Wibbels TR, Morris YA, Owens DW, Dienberg GA, Noell J, Leong JK, King RE, Marquez RM (1989) Predicted sex ratios from the international Kemp's ridley sea turtle head start research project. In: Caillouet CW Jr, Landry AM Jr (eds) 1st Int Symp Kemp's Ridley Sea Turtle Biology, Conservation and Management, Texas A\&M University. Sea Grant College Program, TAMU-SG-89-105, p 77-81

Williams N (1995) A history of the Cayman Islands. 2nd edn. The Government of the Cayman Islands. Bourne Press, Bournemouth

Wood FF, Wood JR (1994) Sea turtles of the Cayman Islands. In: Brunt MA, Davies JE (eds) The Cayman Islands: natural history and biogeography. Kluwer Academic Publishers, Dordrecht, p 229-236

Submitted: May 16, 2006; Accepted: September 20, 2006 Proofs received from author(s): November 13, 2006 